\title{
CHANGES IN INNOVATION ACTIVITY IN REGIONAL INDUSTRIAL SYSTEM \\ IN THE CONTEXT OF SIZE OF ENTERPRISES \\ IN WEST POMERANIAN PROVINCE
}

Prof. Arkadiusz Świadek

University of Zielona Góra

Faculty of Economics and Management

Podgórna 50, 65-246 Zielona Góra, Poland

e-mail:a.swiadek@wez.uz.zgora.pl

Katarzyna Szopik-Depczyńska, Ph.D.

University of Szczecin

Faculty of Economics and Management

Mickiewicza 64, 71-101 Szczecin, Poland

e-mail:kasiasz@wneiz.pl

Received 7 April 2014, Accepted 1 December 2014

\begin{abstract}
In transition countries the firms' size and equity property affect economic processes, including innovation activity in industry. Researche has shown that the key to accelerate economy development is technology transfer from foreign countries. Implementation of new solutions depends on medium and large organizations, rather than on the micro and small ones. Traditional micro and small regional enterprises feature a low level of capacity to take risk. An innovation activity in industry systems grows up over time, but only in small domestic enterprises, and it is similar to their foreign and larger competitors. This paper discusses the problems of size of enterprises and its impact on innovation activity in regional industry systems in West Pomeranian province in the period 2004-2006 and 2009-2011.
\end{abstract}

Keywords: innovativeness, region, industry.

JEL classification: $\mathrm{O} 31, \mathrm{O} 32$. 


\section{Introduction}

Observations conducted in the most developed countries show that despite the growing importance of the economic globalisation, a region is still perceived as the stable alternative possibility of the existence and development of the MSP sector in the new layout of the global market. For this reason the main objective of the regional politics in the countries of the European Union is to ensure the smooth adaptation of regional industrial structures to the global changes of the social, technological and economic indicators ${ }^{1}$.

The problem of the impact of the size on the development of an innovative activity is nothing new. Moreover, the approach to this phenomenon has evolved over time, and the changes were fairly radical. Economists have tried to link economic growth and innovation in the areas of monopoly and large companies since Capitalism, Socialism and Democracy was published by J. Schumpeter ${ }^{2}$. His first hypothesis assumed that economic growth took place in the process of "creative destruction" in the capitalist system. During this process, the "traditional" industrial structures such as products, processes and organizations are constantly subjected to a confrontation with the 'new' innovation activities. This kind of "industrial change (...) is the basis of the functioning of the capitalist economy". This "creative destruction" is seen as the way of leading into higher profits and welfare. At the core of it lies risky innovation activity.

The dynamics and systemic nature of innovation were introduced in the complex-systemoriented Neo-Schumpeterian evolutionary economics ${ }^{4}$. According to this perspective, the innovation process at the enterprise level is considered as a set of activities that are related to each other through mutual feedback, while innovation is the result of an interactive learning process that often involves several actors from inside and outside the company ${ }^{5}$.

It has been found that it is difficult to define a universal system of innovation corresponding to all regions. Each region has a unique historical, geographical and cultural characteristics, different political and social systems, as well as economic and demographic features. In addition, innovation systems are constantly evolving and therefore modern approach to the innovation process is referred to a dynamic interactive model of innovation ${ }^{6}$. The impact of a firm's size on its innovation activity has been discussed many times, but it is still not clear ${ }^{7}$. Moreover, this approach not only has evolved, but it has changed quite dramatically over time. At first, the ability to develop new technology was seen as the domain of large enterprises and imperfect competition $^{8}$. 
In the nineteen eighties, Drucker argued that small and medium enterprises are the most important innovators 9 . The impact of a firm's size on its innovation activity seems to be more heterogeneous in nature than previously assumed. It depends on many other factors ${ }^{10}$. Much evidence exists in favor of the thesis of technological improvement in the economy by stimulating innovation in large entities. Such cases are common in economically underdeveloped countries, where entrepreneurship is not sufficiently developed and widespread". In the "catching up" economies the industrial structure has a high share of low-tech entities which translates into a small share of high technology products in international trade.

Basing on the 10-years period of research on innovation of industrial enterprises in Poland, we assume that the improvement of the structure of international trade of domestic firms is based on the evolutionary changes in both the enterprise size classes as well as their technology ${ }^{12}$. New solutions are generally acquired by passive transfer of technology. The more the company takes part in the international industrial chain, the faster it adapts new technologies ${ }^{13}$. Furthermore, firm size has no effect on the types of implemented innovations. There are, however significant differences between the implementations and the initiation of these processes in companies in the world ${ }^{14}$. It can therefore be concluded, that this polemic has not been completed, and the impact of firm size on the development of new technology seems to be a phenomenon much more diverse than previously thought.

Studies conducted worldwide suggest higher public support for large companies due to higher probability of development for all market, whereas the same support used at SMEs level generates new solutions mainly at companies level ${ }^{15}$. At the same time, a stable trend is supported by the European Commission to stimulate the sector of small and medium-sized enterprises in Poland. As argued A.N. Link, large firms have an innovative advantage in markets with imperfect competition, but small firms are characterized by a higher predominance of innovation in markets similar to the model of perfect competition ${ }^{16}$. Results of analyses conducted in this paper aim to enrich the achievements of the knowledge in this scope, bringing the aforementioned evolution of the regional economic system closer.

The basic research hypothesis of this paper is the statement that the innovative activity in territorial industrial systems and in their connections with the environment, is significantly determined by the impact of the size structure of enterprises. The accurate diagnosis of the progress of innovative processes and their limitations in the regional management system enables the construction of various paths of development of innovative networks. Economic systems which take into account the intraregional specificity will in the future allow the acceleration of the creation, absorption and diffusion of technology. 
The aim of the conducted research was the attempt to identify the changeable conditions of the impact of the size classes of economic subjects on their innovation in the selected regional industrial system. The presented effects of the study include only the selected part of conclusions from the conducted analyses. An important reason of the undertaken works is to indicate the boundary conditions relevant to the model structure of the regional innovation network. The paper also compares results of the studies of the innovative activity of industrial systems in the West Pomeranian region in the interval of five years.

The exemplification layer of studies is based on the factual data from the entities of the West Pomeranian region collected for the years 2004-2006 and 2009-2011. During the works the questionnaire was used addressed to the enterprises forming the Polish Classification of Activities, mainly to the sector of industrial manufacturing. The number of companies participating in the study, selected due to their technological level, corresponds approximately to data published by the Central Statistical Office. The analyses were carried out based on the correctly filled in 447 questionnaires from 2006 and 2011, when 729 entities from the West Pomeranian region participated in the study. The analyses were static and they were conducted in the three-year system, consistent with the methodological standards of the research works on the innovation implemented in OECD countries - Oslo methodology.

\section{Methodological conditions of the conducted research}

The methodological part of the conducted analyses is based on the theory of probability where, if the dependent variable takes the dichotomous values, the multiple regression is characterised by the limited usability. It is often used for the studies of quantitative phenomena. Therefore, the logistic regression was used whose greatest value is the possibility to analyse as well as to interpret the results using the methods similar to the classical method of regression basing on the convergent scheme of variable selection and testing hypotheses. The differences most often refer to a greater complexity and time-consumption of calculations. In extreme cases the determination of the values or the preparation of the residual graphs does not provide anything decisive to the model ${ }^{17}$.

Discrepancies between the probit and logit models focus on the specification in the equation of the distribution of the random factor. The logit model exists when $\mathrm{F}$ is the distribution function of the logistic distribution, and the probit model is obtained when the random factors have the normal distribution ${ }^{18}$. The correlation between the Logit and Probit values is illustrated by the following equation: 


$$
\frac{\text { Logit }}{\text { Probit }}=\frac{\pi}{\sqrt{3}}=1,8
$$

With the methods of a dichotomous variable, the assessment of parameters is carried out using the method of the maximum likelihood (MNW). This method requires finding the vector of variables to guarantee the highest probability of the occurrence of values observed in the sample ${ }^{19}$. This method, when applied in case of small communities, is often more advantageous in comparison with the competing estimators ${ }^{20}$.

The study used the group of four independent variables: the size of economic entities (micro, small, medium and large companies). Dependent variables in this case are mainly:

- the size of expenditures on the innovative activity in connection with their structure ${ }^{21}$,

- the implementation of new processes and products taking into account the specific solutions (new technological processes and new products),

- the subjective approach to the innovative cooperation ${ }^{22}$.

Independent variables adopted in the studies determine the set of reference planes which characterise the innovative activity of economic entities, consistently with the methodology used for the OECD countries ${ }^{23}$. A decision was made to build one factor models, mainly due to large difficulties in the interpretation of the probit modelling. Additionally the possibility for auto-correlation on the side of independent variables was omitted, due to their excluding nature. Given the set target and the research hypothesis, 250 probit models were constructed, from which only a part reached the statistical significance. The designated formulas were set into groups, and then interpreted based on the time system. The five-year break between the periods allows to carry out analyses on the evolution of the studied industrial system.

\section{Characteristics of the study sample}

As it was noted in the introduction to the paper, according to the study conducted in the years 2004-2006, it was possible to obtain information from 447 subjects. In turn, in the years 2009-2011 the survey included 728 industrial enterprises running business in the West

Table 1. Structure of the studied enterprises in relation to time scale of the conducted research

\begin{tabular}{|l|c|c|c|c|}
\hline Size class & Micro & Small & Medium & Large \\
\hline $2004-2006$ & 110 & 159 & 144 & 34 \\
\hline $2009-2011$ & 226 & 317 & 149 & 36 \\
\hline
\end{tabular}

Source: own study based on research. 
Pomeranian region. The table below presents the structure of enterprises, taking into account the class of their size and time scale of the conducted research.

It should be emphasized here that from the perspective of the quantitative attempt, studies conducted by the authors are similar to the studies on the innovation of enterprises conducted by the Central Statistical Office.

\section{The evolution of the industrial innovation in the West Pomeranian region in the studied sub-periods}

In the first period (years 2004-2006) the studies showed that the innovation of industrial enterprises in the West Pomeranian region was not positively dependent on the micro and small companies. Therefore, this means that the greater their number in relation to medium and large companies, the lower the probability of the appearance of the innovative company. The lowest probability of the occurrence of the innovative subject can be observed in the community of "micro" companies and at the same time it concerns all the studied attributes of innovation financing, implementation and cooperation.

Table 2. The value of the parameter with the independent "micro" variable in probit models describing the innovation of the industry in the West Pomeranian region in the years 2004-2006

\begin{tabular}{|l|c|c|c|c|c|c|c|}
\hline \multicolumn{1}{|c|}{ Innovation attribute } & Parameter & $\begin{array}{c}\text { Standard } \\
\text { error }\end{array}$ & $\begin{array}{c}\text { Statistics } \\
\text { of } t \text {-student }\end{array}$ & $P>|z|$ & $p_{1}$ & Chi2 & $\begin{array}{c}p \text {-relevance } \\
\text { of the model }\end{array}$ \\
\hline Expenditures on R\&D & -.365 & 0.146 & -2.450 & 0.01 & 0.26 & 6.376 & 0.01 \\
\hline $\begin{array}{l}\text { Expenditures on new fixed assets } \\
\text { (including): }\end{array}$ & -.392 & 0.151 & -2.599 & 0.01 & 0.72 & 6.658 & 0.01 \\
$\quad \begin{array}{l}\text { - buildings } \\
\text { - machines and technical devices }\end{array}$ & -.641 & 0.156 & -4.124 & 0.00 & 0.18 & 18.001 & 0.00 \\
\hline Computer software & -.706 & 0.147 & -2.082 & 0.04 & 0.69 & 4.288 & 0.04 \\
\hline New products & -.418 & 0.144 & -5.236 & 0.00 & 0.55 & 27.389 & 0.00 \\
\hline New by-product systems & -.849 & 0.158 & -5.359 & 0.00 & 0.16 & 31.241 & 0.00 \\
\hline New support systems & -.587 & 0.149 & -3.936 & 0.00 & 0.23 & 16.134 & 0.00 \\
\hline Cooperation with universities & -.689 & 0.302 & -2.279 & 0.02 & 0.02 & 6.643 & 0.01 \\
\hline Cooperation with national R\&D units & -.646 & 0.264 & -2.447 & 0.01 & 0.03 & 7.281 & 0.01 \\
\hline
\end{tabular}

Source: own study based on research.

Both in the years 2004-2006 and in 2009-2011, in the group of the smallest companies it can be observed that the size of the company influences the innovation of entities in the deactivating way. In all statistically significant models the main parameter reaches the negative value, which means that these companies are usually anti-innovative, taking into account both 
the incurred expenditures on their innovative activity and the effects of their innovative activity, while the largest absolute probability of the appearance of innovative companies concerns companies which incur expenditures on machines and technical devices. It can therefore be stated that analysing the issue of technological innovation in the West Pomeranian region in the systemic way, "micro" enterprises are not technologically innovative, taking into account the implementation of new or improved solutions in the form of products of processes. The same phenomenon applies to the issue of cooperation of "micro" enterprises with other entities. The results of the study have shown that cooperation of this group of enterprises with universities or national research and development units does not have positive influence on their innovation. The probability of the occurrence of innovative companies is also the lowest in this aspect.

Table 3. The value of the parameter with the independent "micro" variable in probit models describing the innovation of the industry in the West Pomeranian region in the years 2009-2011

\begin{tabular}{|l|c|c|c|c|c|c|c|}
\hline \multicolumn{1}{|c|}{ Innovation attribute } & Parameter & $\begin{array}{c}\text { Standard } \\
\text { error }\end{array}$ & $\begin{array}{c}\text { Statistics } \\
\text { of } t \text {-student }\end{array}$ & $P>|z|$ & $p_{1}$ & Chi2 & $\begin{array}{c}p-\text { relevance } \\
\text { of the model }\end{array}$ \\
\hline Expenditures on R\&D & -.520 & 0.108 & -4.796 & 0.00 & 0.22 & 23.707 & 0.00 \\
\hline $\begin{array}{l}\text { Expenditures on new fixed assets } \\
\text { (including): }\end{array}$ & -.371 & 0.108 & -3.434 & 0.00 & 0.69 & 11.716 & 0.00 \\
$\quad \begin{array}{l}\text { - buildings } \\
\text { - machines and technical devices }\end{array}$ & -.591 & 0.118 & -5.013 & 0.00 & 0.15 & 26.559 & 0.00 \\
\hline Computer software & -.249 & 0.104 & -2.398 & 0.02 & 0.63 & 5.727 & 0.02 \\
\hline New products & -.368 & 0.102 & -5.600 & 0.00 & 0.41 & 31.677 & 0.00 \\
\hline New technologies (including): & -.355 & 0.109 & -3.264 & 0.00 & 0.70 & 10.583 & 0.00 \\
$\quad \begin{array}{l}\text { - by-product systems } \\
\text { - support systems }\end{array}$ & -.337 & 0.108 & -3.130 & 0.00 & 0.24 & 9.969 & 0.00 \\
\hline Cooperation with suppliers & -.423 & 0.120 & -3.536 & 0.00 & 0.14 & 13.002 & 0.00 \\
\hline Cooperation with PAN units & -.317 & 0.113 & -2.813 & 0.01 & 0.19 & 8.083 & 0.00 \\
\hline General cooperation & -.515 & 0.192 & -2.679 & 0.01 & 0.03 & 8.195 & 0.00 \\
\hline
\end{tabular}

Source: own study based on research.

In general, however, one can formulate an opinion that the innovative activity of micro companies is significantly weaker than that of other groups of companies. This applies to all the areas in question and both analysed periods. At the same time the observed situation should not be expected to change in the near future, which results from the current economic stagnation. The economic cycle is in fact the fundamental factor determining the innovation of subjects.

The development of models in the case of micro companies leads to the conclusion about the necessity to build different support instruments of this group in the region. It is first and foremost a question of stimulating the pro-innovation awareness. 
Table 4. The value of parameter with the "small" independent variable in probit models describing the innovation of the industry in the West Pomeranian region in the years 2004-2006

\begin{tabular}{|l|c|c|c|c|c|c|c|}
\hline \multicolumn{1}{|c|}{ Innovation attribute } & Parameter & $\begin{array}{c}\text { Standard } \\
\text { error }\end{array}$ & $\begin{array}{c}\text { Statistics } \\
\text { of } t \text {-student }\end{array}$ & $P>|z|$ & $p_{1}$ & Chi2 & $\begin{array}{c}p-\text { relevance } \\
\text { of the model }\end{array}$ \\
\hline Expenditures on R \& D & -.623 & 0.133 & -4.671 & 0.00 & 0.22 & 22.550 & 0.00 \\
\hline New technological processes & -.264 & 0.124 & -2.123 & 0.03 & 0.47 & 4.515 & 0.03 \\
\hline Cooperation with suppliers & -.284 & 0.131 & -2.173 & 0.03 & 0.26 & 4.771 & 0.03 \\
\hline Cooperation with national R \& D units & -.448 & 0.201 & -2.230 & 0.03 & 0.04 & 5.355 & 0.02 \\
\hline General cooperation & -.414 & 0.127 & -3.246 & 0.00 & 0.31 & 10.671 & 0.00 \\
\hline
\end{tabular}

Source: own study based on research.

In the years 2004-2006 innovative behaviour of the small companies was characterised by the lack of willingness to start ventures of innovative character. That concerned the issue of financing the research and development activity, and the issues connected with the implementation of new technological processes in the wide grasp. The situation was similar when it was connected with the launching cross-organisational cooperation of innovative character. The probability of the occurrence of the innovative company was almost zero. Also, the highest probability of the existence of the company of pro-innovative nature, reaching almost 0.5 points, occurred in case of the introduction of new or improved technological processes.

Taking into account the outcome of the conducted study in the next period (2009-2011), the essential system conclusion is the fact that the results of those studies did not show the occurrence of statistically essential models, so as the result of the evolution of the industrial system, in those years small subjects stopped being characterized by their anti-innovative approach. This was the effect of evolutionary technological transformations and changes in the perception of innovation in this group of enterprises.

Medium companies are the innovation core in the region. This results both from the studies conducted in the years 2004-2006, and 2009-2011, when these groups' engagement in innovative activities was expanding, as well as it concerns a greater group of attributes, despite the achieved lower probability values. The latter results, first of all, from the cyclical nature of the innovative activity of enterprises and, secondly, from the study conducted in two periods essentially different in terms of the economic activity - the period of 2004-2006 was the phase of strong revival, while 2009-2011, quite opposite - the period of slowdown. 
Table 5. The value of the parameter with the "medium" independent variable in probit models describing the innovation of the industry in the West Pomeranian region in the years 2004-2006

\begin{tabular}{|l|c|c|c|c|c|c|c|}
\hline \multicolumn{1}{|c|}{ Innovation attribute } & Parameter & $\begin{array}{c}\text { Standard } \\
\text { error }\end{array}$ & $\begin{array}{c}\text { Statistics } \\
\text { of } t \text {-student }\end{array}$ & $P>|z|$ & $p_{1}$ & Chi2 & $\begin{array}{c}p \text { - relevance } \\
\text { of the model }\end{array}$ \\
\hline Expenditures on R\&D & +.778 & 0.130 & 5.972 & 0.00 & 0.56 & 36.184 & 0.00 \\
\hline $\begin{array}{l}\text { Expenditures on new fixed assets } \\
\text { (including): }\end{array}$ & +.449 & 0.158 & 2.852 & 0.00 & 0.88 & 8.522 & 0.00 \\
$\quad \begin{array}{l}\text { - buildings } \\
\quad \text { machines and technical devices }\end{array}$ & +.376 & 0.129 & 2.902 & 0.00 & 0.44 & 8.412 & 0.00 \\
\hline Computer software & +.309 & 0.145 & 2.125 & 0.03 & 0.83 & 4.615 & 0.03 \\
\hline New products & +.839 & 0.162 & 5.184 & 0.00 & 0.90 & 29.988 & 0.00 \\
\hline New technologies (including): & +.361 & 0.130 & 3.118 & 0.00 & 0.44 & 9.716 & 0.00 \\
\hline$\quad$ by-product systems & +.414 & 0.128 & 3.225 & 0.00 & 0.49 & 10.414 & 0.00 \\
\hline Cooperation with suppliers & +.406 & 0.130 & 3.126 & 0.00 & 0.43 & 9.760 & 0.00 \\
\hline Cooperation with universities & +.425 & 0.188 & 2.259 & 0.02 & 0.10 & 5.055 & 0.02 \\
\hline Cooperation with national R\&D units & +.751 & 0.178 & 4.213 & 0.00 & 0.17 & 18.166 & 0.00 \\
\hline General cooperation & +.552 & 0.128 & 4.298 & 0.00 & 0.56 & 18.623 & 0.00 \\
\hline
\end{tabular}

Source: own study based on research.

Table 6. The value of the parameter with the „medium” independent variable in probit models describing the innovation of the industry in the West Pomeranian region in the years 2009-2011

\begin{tabular}{|l|c|c|c|c|c|c|c|}
\hline \multicolumn{1}{|c|}{ Innovation attribute } & Parameter & $\begin{array}{c}\text { Standard } \\
\text { error }\end{array}$ & $\begin{array}{c}\text { Statistics } \\
\text { of } t \text {-student }\end{array}$ & $P>|z|$ & $p_{1}$ & Chi2 & $\begin{array}{c}p \text {-relevance } \\
\text { of the model }\end{array}$ \\
\hline Expenditures on R\&D & +.656 & 0.117 & 5.623 & 0.00 & 0.55 & 31.846 & 0.00 \\
\hline $\begin{array}{l}\text { Expenditures on new fixed assets } \\
\text { (including): }\end{array}$ & +.383 & 0.138 & 2.774 & 0.01 & 0.85 & 8.052 & 0.00 \\
$\quad \begin{array}{l}\text { - buildings } \\
\quad \text { machines and technical devices }\end{array}$ & +.489 & 0.119 & 4.121 & 0.00 & 0.40 & 16.822 & 0.00 \\
\hline Computer software & +.250 & 0.125 & 2.003 & 0.05 & 0.76 & 4.082 & 0.04 \\
\hline New products & +.339 & 0.119 & 2.862 & 0.00 & 0.67 & 8.305 & 0.00 \\
\hline New technologies (including): & +.385 & 0.123 & 2.178 & 0.03 & 0.74 & 4.827 & 0.03 \\
$\quad$ - technological processes & +.286 & 0.116 & 2.454 & 0.01 & 0.62 & 6.054 & 0.01 \\
$\quad$ - by-product systems & +.318 & 0.117 & 2.711 & 0.01 & 0.42 & 7.307 & 0.01 \\
\hline - support systems & +.348 & 0.123 & 2.836 & 0.00 & 0.31 & 7.928 & 0.00 \\
\hline Cooperation with suppliers & +.246 & 0.121 & 2.030 & 0.04 & 0.32 & 4.080 & 0.04 \\
\hline Cooperation with PAN units & +.351 & 0.165 & 2.131 & 0.03 & 0.10 & 4.370 & 0.04 \\
\hline Cooperation with foreign scientific units & +.455 & 0.200 & 2.279 & 0.02 & 0.06 & 4.935 & 0.03 \\
\hline Cooperation with recipients & +.512 & 0.122 & 4.193 & 0.00 & 0.34 & 17.302 & 0.00 \\
\hline General cooperation & +.428 & 0.116 & 3.698 & 0.00 & 0.56 & 13.744 & 0.00 \\
\hline
\end{tabular}

Source: own study based on research.

In most cases, the probability exceeds the value of 0.5 , which significantly distinguishes this group of companies from the others (micro, small and even the large ones). It can be clearly 
seen that medium companies dominate in the aspect of innovativeness in the financial area (the expenditures on the R\&D activity and the material technology), the implementation (the implementation of new or the improvement of the existing products and technological processes) and cooperation (innovative cooperation). The difference and evolution can be noticed in the processes of cooperation between medium companies and other units. In the years 20042006 the cooperation with suppliers, universities and national R\&D units actively influences the innovative activity, while in the years 2009-2011 companies focus on the cooperation of innovative nature with suppliers and recipients, but also with the PAN units and foreign R\&D units. This means that the scientific organisations are still the source of innovation, but at the same time the market participants are still involved, which can be seen through the undertaken cooperation both with the suppliers and customers. Medium companies, therefore, increase the chance for the innovation in the region, but this most of all concerns the area of financing and implementation of new or improved software. However, the fact of the monotonicity of variables in the presented models may have positive meaning .

The observed phenomenon proves the progressive change of the centre of gravity in the region from large entities towards the medium ones. This proves the evolution of the regional industrial system, where the pillar of technological transformations is not the elite group of companies, but it became the phenomenon of more general nature.

Table 7. The value of the parameter with the independent "large" variable in probit models describing the innovation of the industry in the West Pomeranian region in the years 2004-2006

\begin{tabular}{|l|c|c|c|c|c|c|c|}
\hline \multicolumn{1}{|c|}{ Innovation attribute } & Parameter & $\begin{array}{c}\text { Standard } \\
\text { error }\end{array}$ & $\begin{array}{c}\text { Statistics } \\
\text { of } t \text {-student }\end{array}$ & $P>|z|$ & $p_{1}$ & Chi2 & $\begin{array}{c}p-\text { relevance } \\
\text { of the model }\end{array}$ \\
\hline Computer software & +.941 & 0.350 & 2.685 & 0.01 & 0.94 & 9.323 & 0.00 \\
\hline New by-product systems & +.747 & 0.229 & 3.254 & 0.00 & 0.65 & 10.915 & 0.00 \\
\hline New support systems & +.727 & 0.229 & 3.170 & 0.00 & 0.65 & 10.352 & 0.00 \\
\hline Cooperation with foreign scientific unit & +.866 & 0.277 & 3.121 & 0.00 & 0.18 & 8.837 & 0.00 \\
\hline
\end{tabular}

Source: own study based on research.

Taking into account the results of the studies presented in the next tables, large enterprises are undoubtedly an important complement for the innovative processes implemented by medium entities. However, there are differences in the results of studies conducted in the years 2004-2006 and 2009-2011. It can be seen that in the years 2004-2006 the emphasis was laid on the expenditures on the innovative activity only in the form of the purchase of modern software, then in the next years the financing also included the research and development works. In the 
evolution of the industrial system we can thus see that the companies noticed the advantages and potential effects of the R\&D activity. At the same time that had impact on the effects of the innovative activity in the form of new or improved products offered on the market, which could not be seen in the case of the research conducted previously. Continuing the issue of the implementation effects of innovativeness, the constancy in the implementation of new byproduct systems might be seen, regardless of the time of the research.

Table 8 . The value of the parameter with the independent „large" variable in probit models describing the innovation of the industry in the West Pomeranian region in the years 2009-2010

\begin{tabular}{|l|c|c|c|c|c|c|c|}
\hline \multicolumn{1}{|c|}{ Innovation attribute } & Parameter & $\begin{array}{c}\text { Standard } \\
\text { error }\end{array}$ & $\begin{array}{c}\text { Statistics } \\
\text { of } t \text {-student }\end{array}$ & $P>|z|$ & $p_{1}$ & Chi2 & $\begin{array}{c}p-\text { relevance } \\
\text { of the model }\end{array}$ \\
\hline Expenditures on R\&D & +.705 & 0.218 & 3.240 & 0.00 & 0.61 & 10.722 & 0.00 \\
\hline Computer software & +.621 & 0.238 & 2.616 & 0.01 & 0.78 & 7.307 & 0.01 \\
\hline New products & +.549 & 0.253 & 2.165 & 0.03 & 0.83 & 5.074 & 0.02 \\
\hline New by-product systems & +.487 & 0.215 & 2.268 & 0.02 & 0.50 & 5.129 & 0.02 \\
\hline New support systems & +.594 & 0.217 & 2.732 & 0.01 & 0.42 & 7.309 & 0.01 \\
\hline Cooperation with PAN units & +.619 & 0.260 & 2.379 & 0.02 & 0.17 & 5.169 & 0.02 \\
\hline General cooperation & +.427 & 0.216 & 1.979 & 0.05 & 0.58 & 3.954 & 0.05 \\
\hline
\end{tabular}

Source: own study based on research.

Another system difference can be seen in the area of the cooperation of enterprises with other units. While in the years 2004-2006 large companies focused on the cooperation with foreign research and development units, in the years 2009-2011 they had a strong relation with all groups of subjects, especially with the PAN units.

Ascertaining, the current shape of models and their evolution over time tend to the conclusion about the imperative of the creation of strong and permanent support instruments in the region for medium and large subjects, to maintain their high tendency to the activate the innovative activity and the further improvement of dynamics of technological changes, while one should conduct detailed research on the causes of the low innovative activity of micro and small companies.

\section{Conclusions}

The diversity of the innovative activity in the region of Western Pomerania in two research sub-periods, taking into account the size of companies in the industrial system, indicates their slight evolution over time, and consequently slightly different habits in the researched scope. 
The development of the industry is currently very limited due to the current economic cycle and the potential of the economy, being additional tendencies of a negative colouring which only intensify the adverse conditions of the structural nature.

Basically, it can be assumed that the innovative dynamo in the region of Western Pomerania are medium companies supported by large units. Taking into account the objective and natural variation of the number of medium companies in relation to the large ones, the innovative activity concerns a broader group of companies, which contributes to the increased intensity of the knowledge flow in the system.

Anti-innovative behaviour, in turn, concern micro and small companies. From the point of view of the evolutionary system, it would be important to support the innovative activity of small industrial companies. Previous studies conducted by the authors in other, economically strong regions showed that small entities are not the factor de-stimulating the innovative activity, however in the analysed case at this stage of the development we notice the lack of interest in new technologies. This is undoubtedly a strong barrier of the innovative activity in the West Pomeranian region, showing its specificity.

The observed phenomena indicate that relations between enterprises, their previous experiences and market insights, as well as the level of trust in the market and the tendency to implement new technological solutions make the industrial system in the region of Western Pomerania work smoothly, but it should be properly targeted. Considering its potential, one can risk to make a thesis that it has the right critical mass which is able to energise technological changes. It is located mainly in the innovative potential of medium and large companies, so the basic task of the local authorities is to conduct a wide-ranging promotional activity, making the entrepreneurs aware that micro and small companies have to conduct innovation activity and achieve positive effects in this field.

Summing up, the innovative policy in the Western Pomerania region should be focused mostly on maintaining and strengthening the innovation in the sector of medium and large companies. However, one should remember that it is also supposed to take into account the need to use different pro-innovative mechanisms for particular size classes of enterprises. Finally, it should be added that the results of the study should also be compared to the differences between groups size of enterprises. We do not have such possibility, but then the results would have been more complete. 


\section{Notes}

${ }^{1}$ Frenkel (2003).

${ }^{2}$ Schumpeter (2000), p. 83.

${ }^{3}$ Ibidem.

${ }^{4}$ Antonelli (2011); Consoli, Patrucco (2011); Dopfer (2011), Cap. 13.

${ }^{5}$ National Systems... (1992), p. 58.

${ }^{6}$ Gorynia-Pfeffer (2013); Świadek (2012), pp. 5-23.

7 Pérez-Cano (2013), pp. 209-226; Gil, Figueiredo (2013), pp. 129-161; Herrera, Sánchez-González (2013), pp. 137155.

${ }^{8}$ Schumpeter (1960).

${ }^{9}$ Drucker (1992).

${ }_{10}$ Audretsch (1995), p. 175.

11 Janasz (2005), pp. 133-174.

12 Świadek (2007).

13 CASE (2005).

14 Damanpour (1992), p. 375.

15 Herrera, Sánchez-González (2013), pp. 137-155.

${ }^{16}$ Link (1980), pp. 771-782.

17 Stanisz (2007), p. 217.

${ }_{18}$ Maddala (2006), p. 378.

19 Welfe (1988), pp. 73-76.

${ }^{20}$ Ibidem, p. 76.

${ }^{21}$ The study included research and development, investment in new machinery and equipment, investments in buildings and structures, land or new software.

22 Analyses include innovative cooperation with suppliers, customers, competitors, universities, R\&D units and foreign research institutes.

${ }^{23}$ OECD (2005).

\section{References}

Antonelli, C. (2011). Handbook on the Economic Complexity of Technological Change, Cheltenham, UK and Northampton, MA, USA: Edward Elgar.

Audretsch, D. (1995). Innovation and Industry Evolution. Cambridge, MA: MIT Press.

CASE (2005). Sieci innowacji w polskiej gospodarce - stan obecny i perspektywy rozwoju, No. 60. Warszawa

Consoli, D. \& Patrucco, P. (2011). Complexity and the coordination of technological knowledge: the case of innovation platforms. In:Handbook on the Economic Complexity of Technological Change, ed. C. Antonelli. Cheltenham, UK and Northampton, MA, USA: Edward Elgar. 
Damanpour, F. (1992). Organizational Size and Innovation, Organization Studies, 13 (3).

Dopfer, K. (2011). Mesoeconomics: a unified approach to systems complexity and evolution. In: Handbook on the Economic Complexity of Technological Change, ed. C Antonelli. Cheltenham, UK and Northampton, MA, USA: Edward Elgar, Chap. 13.

Drucker, P. (1992). Innowacja i przedsiębiorczość. Praktyka i zasady. Warszawa: PWE.

Frenkel, A. (2003). Barriers and Limitations in the Development of Industrial Innovation in the Region. European Planning Studies, 11 (2).

Gil, P.M. \& Figueiredo, F. (2013). Firm size distribution under horizontal and vertical innovation. Journal of Evolutionary Economics, 23, 129-161.

Gorynia-Pfeffer, N. (2013). Istota koncepcji narodowego systemu innowacji. Gospodarka Narodowa, 1-2.

Herrera, L. \& Sánchez-González, G. (2013). Firm size and innovation policy. International Small Business Journal, 31 (2), 137-155.

Janasz, W. (2005). Zmiany aktywności innowacyjnej Polski w okresie transformacji. In: Innowacje $w$ działalności przedsiębiorstw $w$ integracji z Unią Europejska, ed. W. Janasz (pp. 233-174). Warszawa: Difin.

Link, A.N. (1980). Firm Size and Efficient Enterpreneurial Activity: A Reformulation of the Schumpeterian Hypothesis. Journal of Political Economy, 88 (4), 771-782.

Maddala, G.S. (2006). Ekonometria. Warszawa: Wydawnictwo Naukowe PWN.

National Systems of Innovation: Towards a theory of innovation and interactive learning (1992). Ed. B.-A. Lundvall. London: Pinter.

OECD (2005). Podręcznik Oslo. Zasady gromadzenia i interpretacji danych dotyczacych innowacji. Wydanie trzecie, Paryż.

Pérez-Cano, C. (2013). Firm size and appropriability of the results of innovation. Journal of Engineering and Technology Management, 30 (3), 209-226.

Schumpeter, J. (1960). Teoria rozwoju gospodarczego. Warszawa: PWN.

Schumpeter, J. (2000). Kapitalizm, socjalizm, demokracja. Warszawa: Wydawnictwo Naukowe PWN.

Stanisz, A. (2007). Przystępny kurs statystki. Vol. 2, Kraków: Statsoft.

Świadek, A. (2007). Determinanty aktywności innowacyjnej $w$ regionalnych systemach przemysłowych w Polsce. Szczecin: Wydawnictwo Naukowe Uniwersytetu Szczecińskiego.

Świadek, A. (2012). Wielkość przedsiębiorstw i ich struktura własności a rozwój innowacyjności w regionalnych systemach przemysłowych. Studia Regionalne i Lokalne, 1, 5-23.

Welfe, A. (1988). Ekonometria. Warszawa: PWE. 